\title{
Neurokinin A Depolarizes Neurons of Bullfrog Dorsal Root Ganglia by Suppressing $\mathrm{K}^{+}$Conductances
}

\author{
TAKASHI AKASU AND MASARU ISHIMATSU \\ Department of Physiology, Kurume University School of Medicine, \\ Kurume 830, Japan
}

Received for publication June 19, 1995

\begin{abstract}
Summary: The effect of neurokinin A (NKA) on neurons of bullfrog dorsal root ganglia (DRG) in primary culture was examined by using wholecell patch-clamp methods. Application of NKA $(1 \mu \mathrm{M})$ depolarized the DRG neurons, resulting in spontaneous firing of action potentials. Under voltageclamp condition, NKA $(3 \mathrm{nM}-1 \mu \mathrm{M})$ caused an inward current $\left(I_{\mathrm{NKA}}\right)$ associated with decreased membrane conductance. The $I_{\mathrm{NKA}}$ reversed its polarity at the equilibrium potential for $\mathrm{K}^{+}$. The $I_{\mathrm{NKA}}$ was blocked by extracellular $\mathrm{Ba}^{2^{+}}$ $(1 \mathrm{mM})$ but not by nominally $0 \mathrm{mM} \mathrm{Ca}{ }^{2+}$, tetraethylammonium $(40 \mathrm{mM}), 4-$ aminopyridine $(2 \mathrm{mM})$ or apamin $(50 \mathrm{nM})$. Intracellular $\mathrm{Cs}^{+}$blocked the $I_{\mathrm{NKA}}$. NKA depressed a voltage-dependent non-inactivating $\mathrm{K}^{+}$current, the $\mathrm{M}$ current $\left(I_{\mathrm{M}}\right)$, at potentials more positive than $-55 \mathrm{mV}$. NKA reduced the maximum M-conductance $\left(G_{\mathrm{M}}\right)$ without changing the kinetics of M-channels. NKA also depressed a voltage- and time-independent background $\mathrm{K}^{+}$current, $I_{\mathrm{K}(\mathrm{B})}$. It is concluded that the $I_{\mathrm{NKA}}$ is produced by suppression of both $I_{\mathrm{M}}$ and $I_{\mathrm{K}(\mathrm{B})}$ in bullfrog primary afferent neurons.
\end{abstract}

Key words: dorsal root ganglia - dissociated neurons - tachykinins background $\mathrm{K}^{+}$current - M-current - whole-cell patch-clamp

\section{Introduction}

Mammalian tachykinins, such as substance P (SP), neurokinin A (NKA) and neurokinin $B(\mathrm{NKB})$, have been demonstrated to exist widely in the peripheral and central nervous systems (Ogawa et al. 1985; Leeman et al. 1991; Otsuka and Yoshioka, 1993). NKA-like immunoreactivity co-exists with SP-like immunoreactivity in neurons of rat dorsal root ganglia (DRG) and in the dorsal horn of the spinal cord (Dalsgaard et al. 1985; Ogawa et al. 1985; Lee et al. 1986; Takano et al. 1986; Helke and Niederer, 1990). Molecular cloning of $\mathrm{cDNAs}$ has revealed three distinct types of tachykinin receptors, $\mathrm{NK}_{1}, \mathrm{NK}_{2}$ and $\mathrm{NK}_{3}$ that belong to the GTP binding protein-coupled receptor superfamily (Masu et al. 1987; Hershey and Krause, 1990; Shigemoto et al. 1990). Functional study showed that NKA and NKB depolarized neurons in mammalian sympathetic ganglia (Saria et al. 1985; Konishi et al. 1992). Recently, we also observed that SP produced an inward

\footnotetext{
Reprint requests to: Dr. T. Akasu, Department of Physiology, Kurume University School of Medicine, 67 Asahi-machi, Kurume 830, Japan.
} 
current by suppressing potassium conductances in acutely dissociated neurons of bullfrog DRG (Ishimatsu, 1994). The purpose of the present study is to examine the effect of NKA on neuronal excitability of DRG by using whole-cell patch-clamp methods. The results show that NKA produced depolarizing response by suppressing both a voltage dependent non-inactivating $\mathrm{K}^{+}$current, the M-current $\left(I_{\mathrm{M}}\right.$ ) (Brown and Adams, 1980; Adams et al. 1982a,b; Tokimasa and Akasu, 1990b) and a voltage-independent background $\mathrm{K}^{+}$current, $I_{\mathrm{K}(\mathrm{B})}$ (Ishimatsu, 1994).

\section{Materials and Methods}

\section{Tissue culture}

The methods for the isolation of single neurons of DRG are essentially the same as described previously (Tokimasa and Akasu, 1990a,b). Bullfrogs (Rana catesbeiana) were sacrificed by decapitation and their brains were mechanically destroyed. Isolated DRG were incubated in a Ringer solution containing trypsin (Sigma type XI; $2.5 \mathrm{mg} / \mathrm{ml}$ ) and collagenase (Sigma type A; $0.5 \mathrm{mg} / \mathrm{ml}$ ) at $36{ }^{\circ} \mathrm{C}$ for $15-30 \mathrm{~min}$. The Ringer solution had the following composition (mM): $\mathrm{NaCl}, 112 ; \mathrm{KCl}, 2 ; \mathrm{CaCl}_{2}$, $1.8 ; \mathrm{N}-[2-$ hydroxyethyl]piperazine-N'-2ethanesulphonic acid (HEPES), 4 and tris (hydroxymethyl) aminomethane (Tris), 1. After digestion, DRG cells were dispersed with gentle pipetting and collected by centrifugation at $80 \mathrm{~g}$ for $4-5$ min. The dissociated cells were stored for 2-4 days at $4{ }^{\circ} \mathrm{C}$ in Leibovitz's L-15 medium (GIBCO 320-1415); 10-20\% fetal bovine serum (GIBCO 200-6140 AG) was added and the diluted to $80 \%$ with water in $35 \mathrm{~mm}$ culture dishes (Falcon 3001).

\section{Whole-cell recording}

The dissociated cells were re-suspended in the Ringer solution 2-3 hs before starting the electrophysiological experiment. DRG neurons were pipetted into the recording chamber $(1.5 \mathrm{ml}$ total volume) and continuously superfused (1$3 \mathrm{ml} / \mathrm{min}$ ) with the Ringer solution. The cells having diameter greater than $50 \mu \mathrm{m}$ (A-type cells) were used for whole-cell patch-clamp recording. Pipettes for the whole-cell recording had a tip resistance of 3-6 M $\Omega$, when filled with a solution of the following composition ( $\mathrm{mM}): \mathrm{KCl}$, 100; $\mathrm{MgCl}_{2}, 4$; adenosine 5'-triphosphate sodium ( $\mathrm{Na}_{2}$-ATP), 5; 1,2-bis (o-aminophenoxy) ethane-N, N, N', N'-tetraacetic acid tetraacetoxymethyl salt (BAPTA), 1; and HEPES (sodium salt), 2.5 ( $\mathrm{pH}$ adjusted with $\mathrm{KOH}$ to 7.0 ). Gigaohm-seal ( $\geq 1 \mathrm{G} \Omega$ ) contact between the recording pipette and cell membrane was established by adding a gentle negative pressure to the recording pipette. A sample-and-hold/ voltage-clamp amplifier (Axoclamp-2A: Axon Instruments) was used at the switching frequency of $10-17 \mathrm{kHz}$. The gain of head-stage current was 0.1 , indicating that a clamping current as large as $\pm 20 \mathrm{nA}$ could be applied to the cell. The output of the amplifier was monitored using an oscilloscope (Toshiba, DM1562A), and connected to a digital oscilloscope equipped with a disc recorder (Nicolet, 4094 and XF-44) and with a chart recorder (Nihon Kohden, RJG-4124). All data were stored in a digital recorder (TEAC, RD-1100) for later analysis. Axodata and Axograph softwares (Axon Instruments) operating Macintosh Centris 650 computer (Apple Computer, Inc.) 
were used to command the membrane potential and to analyze membrane currents.

\section{Isolation of $I_{M}$ and $I_{K(B)}$}

To record the M-current $\left(I_{\mathrm{M}}\right), \mathrm{DRG}$ neurons were superfused with a Ringer solution containing tetrodotoxin (TTX; 3 $\mu \mathrm{M}$ ), tetraethylammonium (TEA; $40 \mathrm{mM}$ ), $\mathrm{Cs}^{+}$(2 mM), 4-aminopyridine (4-AP; $2 \mathrm{mM}$ ) and apamin $(50 \mathrm{nM})$ (Tokimasa and Akasu, 1990b). $\mathrm{NaCl}(72 \mathrm{mM})$ was replaced with equimolar choline chloride. HEPES, $4 \mathrm{mM}$ and tris (hydroxymethyl) aminomethane (Tris, $1 \mathrm{mM}$ ) were used as buffer instead of $\mathrm{NaHCO}_{3}$. In this modified Ringer solution, called M-solution, voltage-dependent $\mathrm{Na}^{+}$current, delayed rectifier $\mathrm{K}^{+}$current $\left(I_{\mathrm{DR}}\right)$, A-current $\left(I_{\mathrm{A}}\right)$, H-current $\left(I_{\mathrm{H}}\right)$ apamin-sensitive $\mathrm{Ca}^{2+}$ dependent $\mathrm{K}^{+}$ current $\left(I_{\mathrm{K}-\mathrm{Ca}}\right)$ were eliminated (Tokimasa and Akasu, 1990a,b). To isolate a voltageindependent background $\mathrm{K}^{+}$current $\left(I_{\mathrm{K}(\mathrm{B})}\right)$, DRG neurons were superfused with an M-solution containing nominally zero $\mathrm{Ca}^{2+}$ and $\mathrm{Co}^{2+}(300 \mu \mathrm{M})$, and voltage-clamped at a potential more negative than $-60 \mathrm{mV}$. $\mathrm{Ca}^{2+}$-free Ringer solution contained nominally $0 \mathrm{mM} \mathrm{Ca}^{2+}, 300 \mu \mathrm{M} \mathrm{Co}^{2+}$ and $11 \mathrm{mM}$ $\mathrm{Mg}^{2+}$.

\section{Drugs}

Drugs used in the present study were as follows. Apamin and 4-aminopyridine were purchased from Sigma. Neurokinin A (NKA) was from Peptide Institute Inc. (Osaka). Other drugs were tetrodotoxin (Wako Pure Chemicals Industries, LTD.) and tetraethylammonium chloride (Tokyo Kasei). NKA was applied by either perfusion or a train of 3 pressure pulses (820 psi for $30 \mathrm{~ms}$ ) through a broken-tip pipette utilizing a Picospritzer (General
Valve).

All experiments were carried out at $22-24{ }^{\circ} \mathrm{C}$. The statistics are expressed as mean \pm S.E. of the mean for the cells tested. $\mathrm{pH}$ of the superfusate was adjusted to 7.2.

\section{Results}

NKA-induced inward current in DRG neurons

Acutely dissociated neurons of bullfrog DRG showed the resting membrane potential of $-72.2 \pm 1.6 \mathrm{mV}(\mathrm{n}=163)$ and input resistance of $224 \pm 60 \mathrm{M} \Omega(\mathrm{n}=124)$ in the Ringer solution. NKA $(1 \mu \mathrm{M})$ was applied by a train of three pressure pulses (20 psi for $30 \mathrm{~ms}$ ) through a micropipette placed near the recording cells. DRG neurons $(n=8)$ exhibited a depolarizing response associated with spontaneous firing of action potentials (Fig. 1A). The DRG neurons were voltage-clamped at a given resting membrane potential in the whole-cell configuration. Pressure application of NKA $(1 \mu \mathrm{M})$ produced an inward current $\left(I_{\mathrm{NKA}}\right)$ associated with decreased membrane conductance in 82 out of 87 neurons (Fig. 1B). The remaining cells showed no significant change in the membrane current. The amplitude of the NKA-induced inward current was concentration-dependent. The minimum effective concentration of NKA $(3 \mathrm{nM})$ produced the inward current of $0.35 \pm 0.08 n A(n=6)$. At a concentration of $100 \mathrm{nM}$, NKA produced the maximum response $(1.2 \pm 0.4$ $\mathrm{nA}, \mathrm{n}=8$ ) in the Ringer solution. The $\mathrm{EC}_{50}$ for NKA was $3.4 \mathrm{nM}$ (Fig. 1C). In contrast, NKB $(10 \mu \mathrm{M}-1 \mathrm{mM})$ produced no significant current in DRG neurons.

When DRG neurons were hyperpolarized, the $I_{\mathrm{NKA}}$ decreased in amplitude 


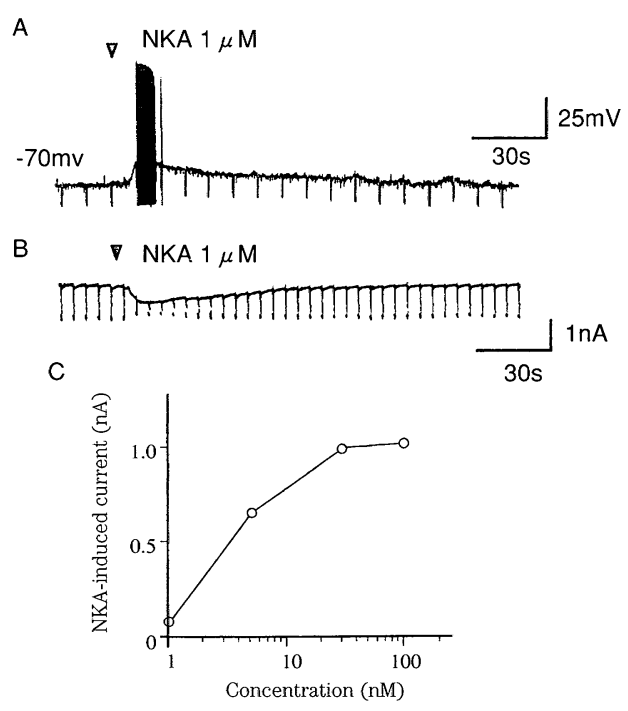

Fig. 1. Effects of NKA on the membrane potential (A) and current (B) in bullfrog DRG neurons. NKA was applied by a train of 3 pressure pulses ( 20 psi for $30 \mathrm{~ms}$ ) through a micropipette filled with $1 \mu \mathrm{M}$ NKA. Filled triangles indicate the time of application of NKA. A: current-clamp recording was made from a DRG neuron superfused with Ringer solution. The resting membrane potential was $-70 \mathrm{mV}$. Downward deflections were electrotonic potentials produced by injection of inward current pulses ( $0.1 \mathrm{nA}$ for $100 \mathrm{~ms}$ ) to the neuron. B: a sample record of the NKA-induced inward current obtained by whole-cell voltage-clamp methods. Downward deflections indicate membrane currents (lower trace) produced by hyperpolarizing step-commands with duration of 300 ms (upper trace). C: concentration- response curve for NKA (1-100 nM). Ordinate and abscissa denote the amplitude of the $I_{\mathrm{NKA}}$ and concentration of NKA. NKA was applied by superfusion for $10 \mathrm{sec}$.

and finally reversed its polarity at a membrane potential between -70 and $-105 \mathrm{mV}$ in the normal $\mathrm{K}^{+}(2 \mathrm{mM})$ Ringer solution (Fig. 2A). The relationship between hold-
A

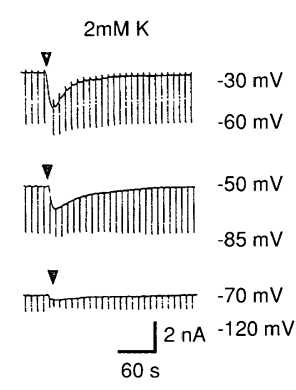

B

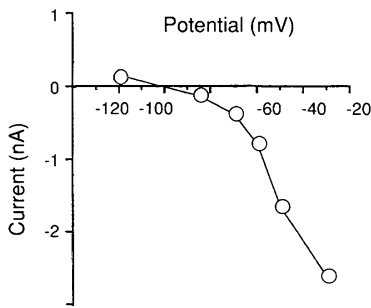

Fig. 2. The reversal potentials of the NKA-induced inward current. A: sample records of the $I_{\mathrm{NKA}}$ obtained from a DRG cell superfused with Ringer solution containing $2 \mathrm{mM} \mathrm{K}^{+}$. Downward deflections indicate inward currents produced by hyperpolarizing voltage-command pulses with duration of $300 \mathrm{~ms}$. Holding membrane potentials are shown between traces. B: relationship between the amplitude of the NKA-induced response and the holding membrane potential. Data were obtained from (A).

ing voltage and amplitude of the $I_{\mathrm{NKA}}$ showed that the reversal potential of the $I_{\mathrm{NKA}}$ was $-100 \mathrm{mV}$ in $2 \mathrm{mM} \mathrm{K}^{+}$Ringer solution (Fig. 2B). From 6 cells, the reversal potentials of the $I_{\mathrm{NKA}}$ were $-98.2 \pm 4.0 \mathrm{mV}$ in Ringer solutions.

\section{Effects of $K^{+}$channel blockers}

Intracellular $\mathrm{Cs}^{+}, \mathrm{a} \mathrm{K}^{+}$channel blocker in neuronal cells (Rudy, 1988; Hille, 1992) was applied through a patch-pipette containing $96 \mathrm{mM}$ CsCl. The holding current $(\mathrm{a}-30 \mathrm{mV}$ ) gradually shifted to the inward direction after rupturing the patch membrane. The inward current produced by 1 $\mu \mathrm{M}$ NKA was strongly reduced in neurons treated with $\mathrm{Cs}^{+}(\mathrm{n}=3)$ (Fig. 3A). Extracellular $\mathrm{Ba}^{2+}$ has been reported to block several types of $\mathrm{K}^{+}$channels in excitable cells (Rudy, 1988; Hille, 1992). 


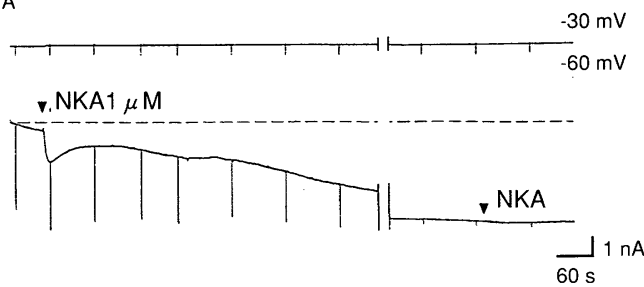

B
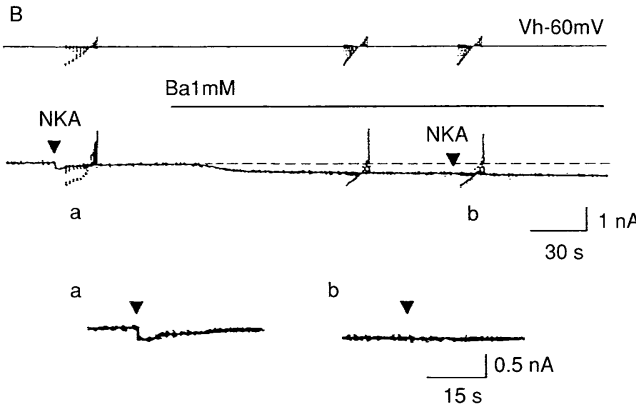

Fig. 3. Effect of $\left[\mathrm{Cs}^{+}\right]_{\mathrm{i}}$ and $\left[\mathrm{Ba}^{2+}\right]_{\mathrm{o}}$ on $I_{\mathrm{K}(\mathrm{B})}$. $A$ : a consecutive recording of the membrane current recorded by a patch-pipette filled with $96 \mathrm{mM} \mathrm{CsCl}$. After rupturing the patch membrane, the ganglion cell was initially held at $-30 \mathrm{mV}$ and subjected to hyperpolarizing voltage-step ( $300 \mathrm{~ms}$ in duration) to $-60 \mathrm{mV}$. NKA-induced inward currents were taken 5 and $40 \mathrm{~min}$ after rupturing the patch membrane. The recordings were interrupted for $15 \mathrm{~min}$ between NKA applications (lower traces). B: effect of $\mathrm{Ba}^{2+}(1 \mathrm{mM})$ on the $I_{\mathrm{NKA}}$ obtained at $-60 \mathrm{mV}$. Horizontal bar indicates the period of bath-application of $\mathrm{Ba}^{2+}$. Lower traces (a) and (b) are expanded records of the $I_{\mathrm{NKA}}$ taken at the times marked with the sauce letters in the trace immediately above.

Bath-application of $\mathrm{Ba}^{2+}(1 \mathrm{mM})$ produced an inward current at $-60 \mathrm{mV}$ and depressed the amplitude of the $I_{\mathrm{NKA}}$ (Fig. $3 \mathrm{~B}) . \mathrm{Ba}^{2+}$ depressed the membrane conductance during the inward current at holding potentials more negative than $-60 \mathrm{mV}$. The reversal potential of $\mathrm{Ba}^{2+}$ - induced current was $-91.2 \pm 5.3 \mathrm{mV}(\mathrm{n}=6)$. It has been demonstrated that SP depolarizes neurons in submucous ganglia by suppressing a $\mathrm{Ca}^{2+}$-dependent $\mathrm{K}^{+}$current, $I_{\mathrm{K}(\mathrm{Ca})}$ (Akasu and Tokimasa, 1989; Morita and Katayama, 1992). However, the $I_{\text {NKA }}$ in DRG neurons was not inhibited in nominally $0 \mathrm{mM} \mathrm{Ca}{ }^{2+}$ Ringer solution containing $300 \mu \mathrm{M} \mathrm{Co}^{2+}$ and $11 \mathrm{mM} \mathrm{Mg}^{2+}(\mathrm{n}=5)$.

\section{Effect of NKA on the $I_{M}$}

A voltage-dependent non-inactivating $\mathrm{K}^{+}$current, the M-current $\left(I_{\mathrm{M}}\right)$ (Brown and Adams, 1980; Adams et al. 1982a,b), has been shown to occur at relatively depolarized membrane potential in neurons of bullfrog DRG (Tokimasa and Akasu, 1990b). To obtain the $I_{\mathrm{M}}$, DRG neurons were superfused with a modified Ringer solution (M-solution) containing TTX $(3 \mu \mathrm{M})$, TEA $(40 \mathrm{mM}), \mathrm{Cs}^{+}(1 \mathrm{mM})$, 4-AP (1 mM) and apamin (30 $\mathrm{nM})$ (Tokimasa and Akasu, 1990b). A hyperpolarizing step command from -30 to -60 $\mathrm{mV}$ produced an instantaneous (ohmic) current followed by an inward relaxation that is due to deactivation of the M-channel (Fig. 4). Upon stepping back to the initial holding potential $(-30 \mathrm{mV})$, DRG cells showed an instantaneous current at $-60 \mathrm{mV}$ followed by an inward tail current due to re-activation of $I_{\mathrm{M}}$ at $-30 \mathrm{mV}$ (Adams et al. 1982a,b; Tokimasa and Akasu, 1990b). Application of NKA $(1 \mu \mathrm{M})$ to the superfusing solution (Msolution) produced the inward current. The amplitude of the $I_{\mathrm{NKA}}$ was $0.8-1.7 \mathrm{nA}$ $(\mathrm{n}=43)$ at $-30 \mathrm{mV}$ (Fig. 4A). During the inward current the $I_{\mathrm{M}}$ was depressed (Fig. 4A). NKA, however, did not change the time course and the reversal potential of the $I_{\mathrm{M}}$. NKA also depressed the instantaneous current recorded at the end of 
A

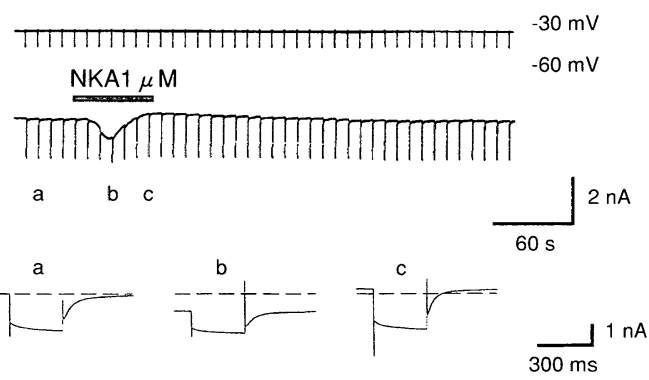

A

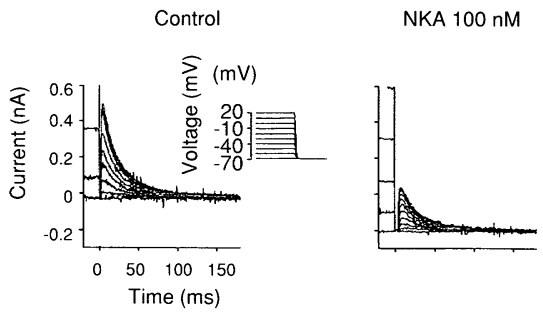

$\overline{\mathrm{B}}$

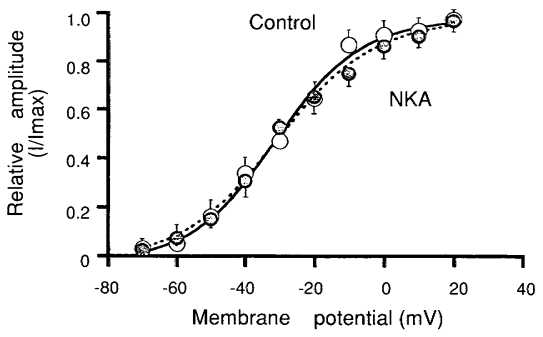

Fig. 5. Effect of NKA on the steady-state activation curve of the $I_{\mathrm{M}}$. A: sample records of the $I_{\mathrm{M}}$ tail current obtained before (left panel) and during (right panel) application of NKA (100 nM). The DRG neuron was initially held at $-70 \mathrm{mV}$ and then subjected to depolarizing voltage command pulses with duration of $300 \mathrm{~ms}$. The amplitude of $I_{\mathrm{M}}$ tail currents was measured $10 \mathrm{~min}$ after termination of the depolarizing voltage-commands. B: graph shows the relationship between the amplitude of the tail current (ordinate) and holding voltage (abscissa). The data were obtained from the records shown in (A). The maximum amplitude of the tail current obtained at $+20 \mathrm{mV}$ represents 1.0 . Open and filled circles were obtained in the absence and presence of NKA $(100 \mathrm{nM})$, respectively. Curves were drawn according to the Boltzmann equation (see Text).

-60 and $+20 \mathrm{mV}$, of $300 \mathrm{~ms}$ duration (Tokimasa and Akasu, 1990a,b). The outward tail current was measured $10 \mathrm{~ms}$ after termination of the depolarizing step command (Fig. 5A). NKA (100 nM) depressed 
the $I_{\mathrm{M}}$; the tail current of the $I_{\mathrm{M}}$ was depressed by $56 \pm 8 \%(n=43)$ at all holding potentials tested. The amplitude of the tail current relative to its maximum value $\left(I / I_{\max }\right)$ was plotted as a function of membrane potential $(V)$ to obtain the steady-state activation curve of the $I_{\mathrm{M}}$ (Fig. 5B). The tail current of the $I_{\mathrm{M}}$ appeared at a potential of $-60 \mathrm{mV}$ and increased in amplitudes as the membrane of DRG cells was depolarized. The maximum amplitude $\left(I_{\max }\right)$ of the tail current was obtained between +10 and $+20 \mathrm{mV}$, indicating the top of the activation curve $(n=8)$. The curve could be described by Boltzmann equation, $I / I_{\max }=$ $[1+\exp ((A-V) / k)]^{-1}$, where $A$ and $k$ denote the half-activation voltage and the slope factor, respectively (Tokimasa and Akasu, $1990 a$ ). The half-activation voltage was $-32.4 \pm 1.3 \mathrm{mV}(\mathrm{n}=4)$ and $-30.8 \pm 0.9 \mathrm{mV}$ $(\mathrm{n}=4)$, respectively in the absence and presence of NKA $(100 \mathrm{nM})$. The slope factors were $21.1 \pm 0.7 \mathrm{mV}(\mathrm{n}=4)$ in control and $19.5 \pm 1.1 \mathrm{mV}(\mathrm{n}=4)$ in the presence of $100 \mathrm{nM}$ NKA.

Effect of NKA on background $K^{+}$current, $I_{K(B)}$

The contribution of non-M type $\mathrm{K}^{+}$ current to the $I_{\mathrm{NKA}}$ was examined at the resting membrane potential where the $I_{\mathrm{M}}$ is strongly deactivated. DRG neurons were voltage-clamp at $-60 \mathrm{mV}$ and were superfused with an M-solution containing nominally zero $\mathrm{Ca}^{2+}, \mathrm{Co}^{2+}(300 \mu \mathrm{M})$ and $\mathrm{Cs}^{+}$ $(1 \mathrm{mM})$ to eliminate the $I_{\mathrm{M}}, \mathrm{Ca}^{2+}$-induced $\mathrm{K}^{+}$current and $\mathrm{H}$-current (Tokimasa and Akasu, 1990a,b). Hyperpolarizing voltagecommands (400 ms in duration) from -60 to $-120 \mathrm{mV}$ produced a square (ohmic) inward current associated with no obvious current relaxation (Fig. 6A). Bath-appli- cation of NKA $(100 \mathrm{nM})$ produced a 0.5 $1 \mathrm{nA}(0.23 \pm 0.05 \mathrm{nA}, \mathrm{n}=10)$ inward shift of the holding current at $-70 \mathrm{mV}$ and depressed the amplitude of ohmic currents produced by hyperpolarizing voltagesteps (Fig. 6A). NKA (100 nM) decreased the slope conductance by $5-20 \mathrm{nS}(\mathrm{n}=4)$ at potentials between -60 and $-130 \mathrm{mV}$. In this particular neuron, the linear $I-V$

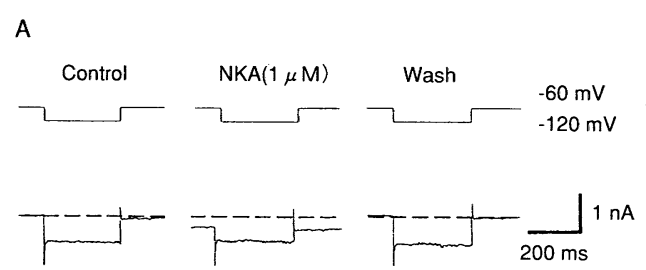

B

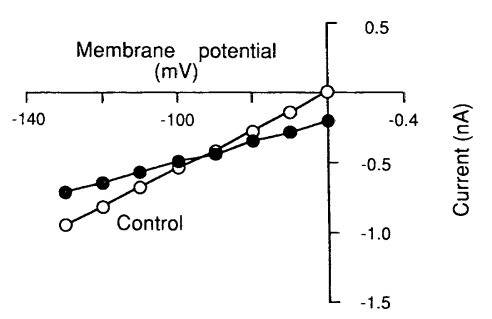

Fig. 6. Effect of NKA on background $\mathrm{K}^{+}$ current, $I_{\mathrm{K}(\mathrm{B})}$. DRG neuron superfused with the M-solution containing nominally $0 \mathrm{mM}$ $\mathrm{Ca}^{2+}, \mathrm{Co}^{2+}(300 \mu \mathrm{M})$ and $\mathrm{Cs}^{+}(1 \mathrm{mM})$. A: the neuron was initially held at $-60 \mathrm{mV}$. Ohmic (square) current, $I_{\mathrm{K}(\mathrm{B})}$, was produced by hyperpolarizing step-pulse from -60 to $-110 \mathrm{mV}$. Left and middle records and are the $I_{\mathrm{M}}$ taken before and after application of NKA $(1 \mu \mathrm{M})$. Right record was taken $25 \mathrm{~min}$ after withdrawal of NKA. B: current-voltage relationships obtained from a DRG cell superfused with an external solution as described in (A). Open and filled circles were taken before and during the application of NKA $(1 \mu \mathrm{M})$. The neuron was initially held at $-60 \mathrm{mV}$. 
curve intersected the control curve at $-96 \mathrm{mV}$. From 4 cells, the reversal potential of the $I_{\mathrm{NKA}}$ was $-96.2 \pm 4.1 \mathrm{mV}$ (Fig. $6 \mathrm{~B})$.

\section{Discussion}

Present study showed that NKA (3 $\mathrm{nM}-1 \mu \mathrm{M})$ caused the depolarization associated with spontaneous firing of action potentials in neurons of bullfrog DRG. Under voltage-clamp, NKA caused the inward current, $I_{\mathrm{NKA}}$, associated with a decreased membrane conductance. The $I_{\mathrm{NKA}}$ reversed polarity at the equilibrium potentials of $\mathrm{K}^{+}$. The substitution of $\mathrm{Cs}^{+}$ for $\mathrm{K}^{+}$in the pipette-solution, which generally blocks $\mathrm{K}^{+}$channels in neuronal cells (Rudy, 1988; Hille, 1992), strongly reduced the $I_{\mathrm{NKA}}$. $\mathrm{Ba}^{2+}$, a channel blocker (Adams et al. 1982a,b; Tokimasa and Akasu, 1990b), also reduced the $I_{\mathrm{NKA}}$ at $-60 \mathrm{mV}$. These results suggest that the $I_{\mathrm{NKA}}$ is produced mainly by depression of a $\mathrm{K}^{+}$conductance in DRG neurons. The $I_{\mathrm{NKA}}$ was not blocked by TEA $(40 \mathrm{mM})$, $\mathrm{Cs}^{+}(2 \mathrm{mM}), 4-\mathrm{AP}(1 \mathrm{mM})$ and apamin $(50 \mathrm{nM})$, suggesting that the delayed rectifier current, the inward rectifier current and A-current are not involved in the $I_{\mathrm{NKA}}$ in neurons of bullfrog DRG (Tokimasa and Akasu, 1990a,b). SP has been reported to suppress the $I_{\mathrm{K}(\mathrm{Ca})}$, in neurons of guinea-pig submucous and myenteric ganglia (Akasu and Tokimasa, 1989; Morita and Katayama, 1992). However, the $I_{\mathrm{K}(\mathrm{Ca})}$ may not contribute to the $I_{\mathrm{NKA}}$ in bullfrog DRG neurons, because 1) the $I_{\mathrm{NKA}}$ can be recorded from DRG neurons that had been dialyzed with a pipette solution containing nominally $0 \mathrm{mM} \mathrm{Ca}^{2+}$ and BAPTA $(1 \mathrm{mM})$ and 2) $I_{\mathrm{NKA}}$ was not blocked in a nominally $\mathrm{Ca}^{2+}$-free solution containing $\mathrm{Co}^{2+}(300 \mu \mathrm{M})$ and $\mathrm{Mg}^{2+}(11 \mathrm{mM})$ and 3) apamin (30 nM) did not block the $I_{\mathrm{NKA}}$.

It has been reported that the $I_{\mathrm{M}}$ occurs at relatively depolarized membrane potentials in bullfrog DRG neurons (Tokimasa and Akasu, 1990b). In the present study, the $I_{\mathrm{NKA}}$ was associated with suppression of the $I_{\mathrm{M}}$ relaxation produced by hyperpolarizing voltage-command from -30 to $-60 \mathrm{mV}$. NKA did not alter the activation and deactivation time courses, or the reversal potential, of the $I_{\mathrm{M}}$. The activation curve for the M-conductance $\left(G_{\mathrm{M}}\right)$ showed that NKA did not change the half activation voltage. These results indicate that NKA reduces the maximum $G_{\mathrm{M}}$ but does not change the opening and closing kinetics of M-channels. Thus, the suppression of $I_{\mathrm{M}}$ may contribute to the mechanism underlying the $I_{\mathrm{NKA}}$ at relatively depolarized membrane potentials in neurons of bullfrog DRG. The present study clearly showed that NKA produced the current response in at the resting membrane potential of $-72.2 \pm 1.6 \mathrm{mV}$, where the M-channels are deactivated (Adams et al. 1982a,b; Tokimasa and Akasu, $1990 a, b)$. This implies that a potassium current other than the $I_{\mathrm{M}}$ is involved in the $I_{\mathrm{NKA}}$ at the resting membrane potential. An ohmic inward current produced by a voltage-command from the resting membrane potential to hyperpolarizing potentials was depressed during the $I_{\mathrm{NKA}} \cdot I-V$ curves showed that the $I_{\mathrm{NKA}}$ reversed polarity at the equilibrium potential of $\mathrm{K}^{+}$. Such a NKA-sensitive voltage-independent $\mathrm{K}^{+}$current occurring at the resting membrane potential has been termed a background potassium current $\left(I_{\mathrm{K}(\mathrm{B})}\right)$ in bullfrog DRG neurons (Ishimatsu, 
1994). The NKA-induced inward current and is due primarily to the reduction of $I_{\mathrm{K}(\mathrm{B})}$ at the resting membrane potential.

Tachykinins are putative transmitter peptides of primary sensory neurons mediating the transmission of sensory information (see Review Otsuka and Yoshioka, 1993). Tachykinins cause enhancement or depression of nociceptive responses in substantia gelatinosa cells of the cat dorsal horn, by modifying both the release of a sensory transmitter and the membrane excitability of the postsynaptic membrane (Henry, 1980; Otsuka and Yanagisawa, 1987; Otsuka and Yoshioka, 1993). NKA may depolarize the central terminals of primary afferent neurons, resulting in the facilitation of nociceptive transmission in spinal cord.

Acknowledgments: Most of this study was supported by The Ishibashi Research Fund and a Grant-in-Aid for Scientific Research from the Ministry of Education, Science and Culture of Japan.

\section{References}

Adams, P.R., Brown, D.A. and Constanti, A. (1982a). M-currents and other potassium currents in bullfrog sympathetic neurones. J. Physiol. 330, 537-572.

Adams, P.R., Brown, D.A. and Constanti, A. (1982b). Pharmacological inhibition of the Mcurrent. J. Physiol. 332, 223-262.

Akasu, T. and Tokimasa, T. (1989). Potassium currents in submucous neurones of guineapig caecum and their synaptic modification. J. Physiol. 416, 571-588.

BRown, D.A. and Adams, P.R. (1980). Muscarinic suppression of a novel voltage-sensitive $\mathrm{K}^{+}$ current in a vertebrate neurone. Nature 283, 673-676.

Dalsgaard, C.-J., Haegerstrand, A., Theodorsson-
Norheim, E., Brodin, E. and HöKFElt, T. (1985). Neurokinin A-like immunoreactivity in rat primary sensory neurons; coexistence with substance P. Histochemistry 83, 37-39.

HelKe, C.J. and NiEDERER, A.J. (1990). Studies on the coexistence of substance $\mathrm{P}$ with other putative transmitters in the nodose and petrosal ganglia. Synapse 5, 144-151.

HenRY, J.L. (1980). Substance P and pain: an update. TINS 3, 95-97.

Hershey, A.D. and Krause, J.E. (1990). Molecular characterization of a functional cDNA encoding the rat substance $\mathrm{P}$ receptor. Science 247, 958-962.

HilLe, B. (1992). In Ionic channels of excitable membranes, 2ed., Sunderland, MA: Sinauer Associates Inc.

Ishimatsu, M. (1994). Substance P produces an inward current by suppressing voltagedependent and -independent $\mathrm{K}^{+}$currents in bullfrog primary afferent neurons. Neurosci. Res. 19, 9-20.

Konishi, S., Song, S.-Y., Ogawa, T. and Kanazawa, I. (1992). Fast and slow depolarizations produced by substance $\mathrm{P}$ and other tachykinins in sympathetic neurons of rat prevertebral ganglia. Neurosci. Res. 14, 81-95.

Lee, C.-M., Campbell, N.J., Williams, B.J. and IVERSEN, L.L. (1986). Multiple tachykinin binding sites in peripheral tissues and in brain. Eur. J. Pharmacol. 130, 209-217.

Leeman, S.E., Krause, J.E. and Lembeck, F. (1991). Substance $\mathrm{P}$ and related peptides: cellular and molecular physiology. Ann. N. Y. Acad. Sci. 632, 1-497.

Masu, Y., Nakayama, K., Tamaki, H., Harada, Y., Kuno, M. et al. (1987). cDNA cloning of bovine substance-K receptor through oocyte expression system. Nature 329, 836-838.

Morita, K. and Katayama, Y. (1992). Substance P inhibits activation of calcium-dependent potassium conductances in guinea-pig myenteric neurones. J. Physiol. 447, 293-308.

Ogawa, T., Kanazawa, I. and Kimura, S. (1985). Regional distribution of substance $P$, neurokinin $\alpha$ and neurokinin $\beta$ in rat spinal cord, nerve roots and dorsal root ganglia, and the 
effects of dorsal root section or spinal transection. Brain Res. 359, 152-157.

Otsuka, M. and Yanagisawa, M. (1987). Does substance $\mathrm{P}$ act as a pain transmitter? TIPS 8, 506-510.

Otsuka, M. and Yoshioka, K. (1993). Neurotransmitter functions of mammalian tachykinins. Physiol. Rev. 73, 229-308.

Rudy, B. (1988). Diversity and ubiquity of $\mathrm{K}$ channels. Neuroscience 25, 729-749.

SARIA, A., MA, R.C. and Dun, N.J. (1985). Neurokinin A depolarizes neurons of the guinea pig inferior mesenteric ganglia. Neurosci. Lett. 60, 145-150.

Shigemoto, R., Yokota, Y., Tsuchida, K. and NAKANISH, S. (1990). Cloning and expression of a rat neuromedin K receptor cDNA. J. Biol. Chem. 265, 623-628.

Takano, Y., Nagashima, A., Masui, H., Kuromizu, K. and KaniYA, H. (1986). Distribution of substance $\mathrm{K}$ (neurokinin $\mathrm{A}$ ) in the brain and peripheral tissues of rats. Brain Res. 369, 400-404.

Tokimasa, T. and Akasu, T. (1990a). Cyclic AMP regulates an inward rectifying sodiumpotassium current in dissociated bull-frog sympathetic neurones. J. Physiol. 420, 409429.

TOKIMASA, T. and AKasu, T. (1990b). ATP regulates muscarine-sensitive potassium current in dissociated bull-frog primary afferent neurones. J. Physiol. 426, 241-264. 